\title{
The Economy Base of Tourism Industry in Sri Lanka
}

\author{
http://doi.org/10.21272/fmir.5(3).23-32.2021
}

Adhiga Manik Jayasundera

Professor, University of Peradeniya, Kandy, Sri Lanka

\begin{abstract}
The main purpose of the research is to contribute to developing knowledge in tourism industry of Sri Lanka. In this paper the author highlights some areas which should be properly explored for the sustainable growth in the sector of tourism and economic development in Sri Lanka. The author recommends promoting Sri Lanka as a product to the tourists, it is necessary to concentrate on the quality of the product as it helps in lengthening the duration of stay for current customers and thereby emerging new customers. Sri Lanka has a long history of tourism, dating back to the times of King Rawana's period (about 4000 years ago). According to different sources of historical accounts, many of the foreigners have visited Sri Lanka for many different reasons from various regions. Indian ancient calligraphy provide ample evidence of Hanuman and Prince Rama visited Sri Lanka not as tourists in the modern sense, but for a different reason about 4000 years ago. Local ancient chronicles also mention about Venerable Fa Hien from China, Marco Polo from Italy and Ibn Battuta from Arab also have visited Sri Lanka. The first Asians who visited were Arabs for trading purposes in $2^{\text {nd }}-3^{\text {rd }}$ Century A.D. and later Portuguese landed by a mistake in early $16^{\text {th }}$ Century (1505 A.D.), followed by Dutch and British culminating as invaders. Tourism in Sri Lanka is growing rapidly, for centuries and has been a popular place of attraction for foreign travelers. Tourist income is one of the important segments that contribute to the Sri Lankan economy. After Sri Lanka's Independence in 1948 the promotion of tourism was considered by re-establishing the Ceylon Tourist Board which took over the function of the Tourist Bureau. More formal recognition for the country's tourism sector was given with the enactment of Act No.10 of 1966 as Sri Lanka Tourist Board. The history of Sri Lanka helps to understand better this country, its culture, social and environmental impact and economic growth.
\end{abstract}

Keywords: tourist attractions and arrivals, national income and tourism revenues, social and environmental impact, distribution of employment in tourism, economic growth through tourism.

JEL Classification: B00, G59, L83.

Cite as: Jayasundera, A.M. (2021). The Economy Base of Tourism Industry in Sri Lanka. Financial Markets, Institutions and Risks, 5(3), 23-32. http://doi.org/10.21272/fmir.5(3).23-32.2021

Received: 22, July, $2021 \quad$ Accepted: 26, August, $2021 \quad$ Published: 13, September, 2021 (c) (i) Copyright: (C) 2021 by the author. Licensee Sumy State University, Ukraine. This article is an open access article
distributed under the terms and conditions of the Creative Commons Attribution (CC BY) license (https://creativecommons.org/licenses/by/4.0/)

\section{Introduction}

According to Tourism Authority there are seven classified regions suitable for tourism development in Sri Lanka. When Government decided to develop the tourism sector as a separate sector of the country's economy in 1966 there were 18,969 foreign tourists in Sri Lanka. There was an upward trend of tourist arrivals until 1982, with the exception of 1971. Between 1976 and 1982, tourist arrivals had increased 24\% per year. The tourist traffic in 1982 showed that there was a remarkable growth in number of tourists with 407,230 arrivals. However, with the beginning of the civil war in 1983, the growth of tourism declined till 2009. When the Government forces defeated terrorism, in 2009 the arrivals shot up to 448,000 and in 2015 to $1,798,380$, showing over $300 \%$ growth in six years.

Even though there are challenges and threats for future tourism in Sri Lanka comfortable accommodation and restaurant facilities comprehensively renewed to enhance tourism of the country. But Sri Lanka is facing several issues in this sector with higher tourist arrivals. Comfortable accommodations and Tourist Board approved restaurant are not enough to handle the capacity of tourist sector. Past dark year conflicts environment adversely affected to tourism industry and it is vigorously affected to decline economic development of the country. According to history, Sri Lanka survived with agriculture crops and industries but now in need to develop with much stronger and different economic strategies. Therefore Sri Lanka needs 
to enhance tourism sector development with proper Government mediations. Yet Sri Lanka is a great tourism destination and it is popular among most Europeans. This island is compact of $65610 \mathrm{sq} . \mathrm{km}$. in biodiversity, heritage, culture, customs and a glorious past is in a very widen range than other countries. Sri Lankan Government should be needed to mediate to solve tourism sector issues, especially in Sri Lanka tourism sector need large number of professionals in each field. Therefore, Government should implement training and development programmes or standardization methods to categories tourism sector employees as standard level.

\section{Tourist Attractions and Arrivals}

The Democratic Socialist Republic of Sri Lanka is an island in the Indian Ocean located towards the Southern tip of Indian sub-continent. The Strait of Palk that separates Sri Lanka from India and there was a bridge made out of rocks about 4000 years ago. It is renowned as Rama's bridge is nearly 30 miles across the sea, joining Rameshwaram in South India and Thammanar island in Sri Lanka which is the first attraction of the country. The second is Kudiramalei port/cape which is located to the south of Mannar territory in North West. Princess Kuwanna/Kuweni had resided at Kali Villu palace closer to Kudiramalei. These two locations are bordering within Wilpattu National park in North West.

According to history the first Kingdom was Anuradhapura in North Central Province which lasted nearly 1500 years leaving remarkable archaeological sites and a glorious past to the nation. Sri Maha Bodhi the Sacred Bo tree, which was brought down from India, Ruwanweli stupa, Abhayagiri stupa, Jethawanarama stupa, Awkana rock, Samadhi statue, Sigiriya fortress, Stone Inscriptions with Epigraphy, Conferred Caves and all amazing irrigational systems are a few of the tourist attractions at Anuradhapura. The second Kingdom was Polonnaruwa which is located towards the Eastern part of the country, and it lasted nearly 200 years. This Kingdom is rich in many artistically designed and carved edifices, temples, Royal Chambers, massive Palaces, and inscriptions, which are the most tourist attractions in Sri Lanka. Kingdom of Kandy is the main place for all Buddhist as the Sacred Tooth Relic is placed in Kandy King's palace called Dalada Maligawa. The Kandy Pageant renowned as "Esala Perahera or Dalada Perahera "will display annually in the month of August for 10 long days, with spectacular folk dancing, where most tourists will witness. Tourism industry is also widely spread along sunny eye catching wide sandy beaches around the island during the foreigners' winter seasons. As a tourist destination need more guidelines, tour guides, agile transport, comfortable accommodation, food, sanitation and restaurant facilities along with skilled and trained personnels; Large number of persons are engaged in this massive business as well as they are professionally qualified in the fields of multiple languages, friendly manner and awareness of Sri Lankan history to deliver the knowledge to tourists - which is the secret of tourist attraction - Sri Maha Bodhi, Awkana, Ruwanweli, Paras Palace, Twin Ponds, Sigiri,Dalada Perahera.

Table 1. Arrivals of short-term basis 2016, 2017

\begin{tabular}{|l|c|c|c|}
\hline \multicolumn{1}{|c|}{ Rank } & Country & 2016 & 2017 \\
\hline 01. & India & 356,729 & 284,628 \\
\hline 02. & China & 271,577 & 201,879 \\
\hline 03. & U.K. & 188,159 & 130,227 \\
\hline 04. & Germany & 133,275 & 81,281 \\
\hline 05. & Australia & 74,496 & 97,282 \\
\hline 06. & France & 96,440 & 59,479 \\
\hline 07. & USA & 54,254 & \\
\hline
\end{tabular}

Source: Compiled by the author.

Including all the other countries the total arrivals in 2016 was 2,050,832 and in 2017 it was 2,116,407 registering 3.2\% increase.Tourist Board has functioned as the state agency, responsible for development and promotion of the tourism sector in Sri Lanka. Colombo city is the main centre for business activities, conferences and sport events in the country which serves as both a gateway and stopover point for international tourists. Along Western coast Negombo, Mt. Lavinia, Kalutara, Bantota, Beruwela upto Galle are sub points of the tourist attraction. In the Southern region is extending from Galle to Hambantota- Yala sanctuary, in the Eastern region from Kumana birds reserve to Arugambay - Nilaveli are important in tourism. Nuwara-Eliya, Bandarawela, Marawila are some of the other areas where tourists mostly visit. Sri Lanka is rich in five World Heritage Sites viz: Anuradhapura Kingdom, Polonnaruwa Kingdom, Kandy Kingdom, Dambulla and Sigiriya. Excluding these heritage sites tourists visit Yala, Wilpattu, Wasgamuwa, Minneriya, Uda Walawe, Pinnawela 
(Elephants' Park) and Kumana birds national parks. Tourists attractions are classifiable as natural or anthropogenic. Natural attractions include nature spots, flora and fauna, and places with pleasant favourable climate. Anthropogenic attractions include archaeological, cultural, historical, religious sites, performing dances, folklore, handicraft and artifacts. Europe became the largest source of tourist traffic to Sri Lanka with $50 \%$ of total traffic received in January 2020. Asia and Pacific accounted for $40 \%$ of total traffic, Americas $6 \%$, Middle East 3\% and Africa 1\% in 2020. In comparison to January last year the highest decline of 27.4 was recorde4d for Af5rican region while Asia and Pacific recorded a decline 7.7\%. Europe recorded a decline of $7.5 \%$ whereas Americas recorded a decline of 3.7\%. It is noteworthy that Middle East has recorded an increase of $41 \%$ in arrivals after suicide bomb attacks on churches and hotels on Easter Sunday in 2019, and Saudi Arabia has recorded an increase of $122.5 \%$ of arrivals this year. According to the latest data from the Tourism Ministry, total number of international tourist arrivals to Sri Lanka in January 2020 declined by $6.5 \%$ with the arrival of 228,434 in the country. In comparison, 244,239 arrivals were recorded in January 2019. According to the latest reports before Covid 19 situation, the largest source market for tourists was India followed by China and United Kingdom. (Sri Lanka tourist arrivals down 70.8\% in March 2020) The United Kingdom, Russian Federation, Germany, India China were Sri Lanka's top five international tourist generating markets in early 2020.

Table 2. Tourist arrivals January - March 2020

\begin{tabular}{|c|c|c|c|}
\hline India & 12,600 & Australia & 2,590 \\
\hline Russia & 8,800 & Maldives & 2,183 \\
\hline United Kingdom & 7,969 & Ukraine & 2,155 \\
\hline Germany & 6,608 & China & 1,688 \\
\hline France & 4,056 & Poland & 1,638 \\
\hline
\end{tabular}

Source: Compiled by the author.

\section{National Income \& Tourism Revenue}

Tourist income is one of the important segments that contribute to the Sri Lankan economy. Recent trends of Sri Lankan Gross Domestic Production (GDP) show a significant role which played by the service sector indicating a large contribution while tourism stands at the third position in the platform. Tourism related activities play a critical role in generating tourism income, foreign direct investments, employment opportunities as well as increasing gross domestic production. It is also notified that stable political condition is positively influenced on tourism income for a long-term growth. When considering average tourism contribution to Sri Lankan economy it is Rs.58,731.51 million from its inception of 1978, the first Republican Constitution with the introduction of Open Economy System. Sri Lanka's tourism revenue reached nearly USD 4 billion in December 2019 and it is updating yearly available from 1966 - 2019. The contribution of Travel and Tourism to GDP was at level of $12.5 \%$ in 2018.

Table 3. Public Sector Revenue from Tourism (In Rs. Million) 2018

\begin{tabular}{|l|c|}
\hline \multicolumn{1}{|c|}{ Central Cultural Fund } & $4,199.50$ \\
\hline Embarkation tax on foreign tourists & $2,828.90$ \\
\hline Wildlife parks & $2,138.40$ \\
\hline Tourism Development levy & $1,482.10$ \\
\hline Zoological gardens & 698.8 \\
\hline Botanical gardens & 673.4 \\
\hline BMICH & 464.8 \\
\hline Income of Tourism Development Authority & 248.6 \\
\hline Museums & 76 \\
\hline Conservation forests & 66.1 \\
\hline
\end{tabular}

Source: Compiled by the author. 


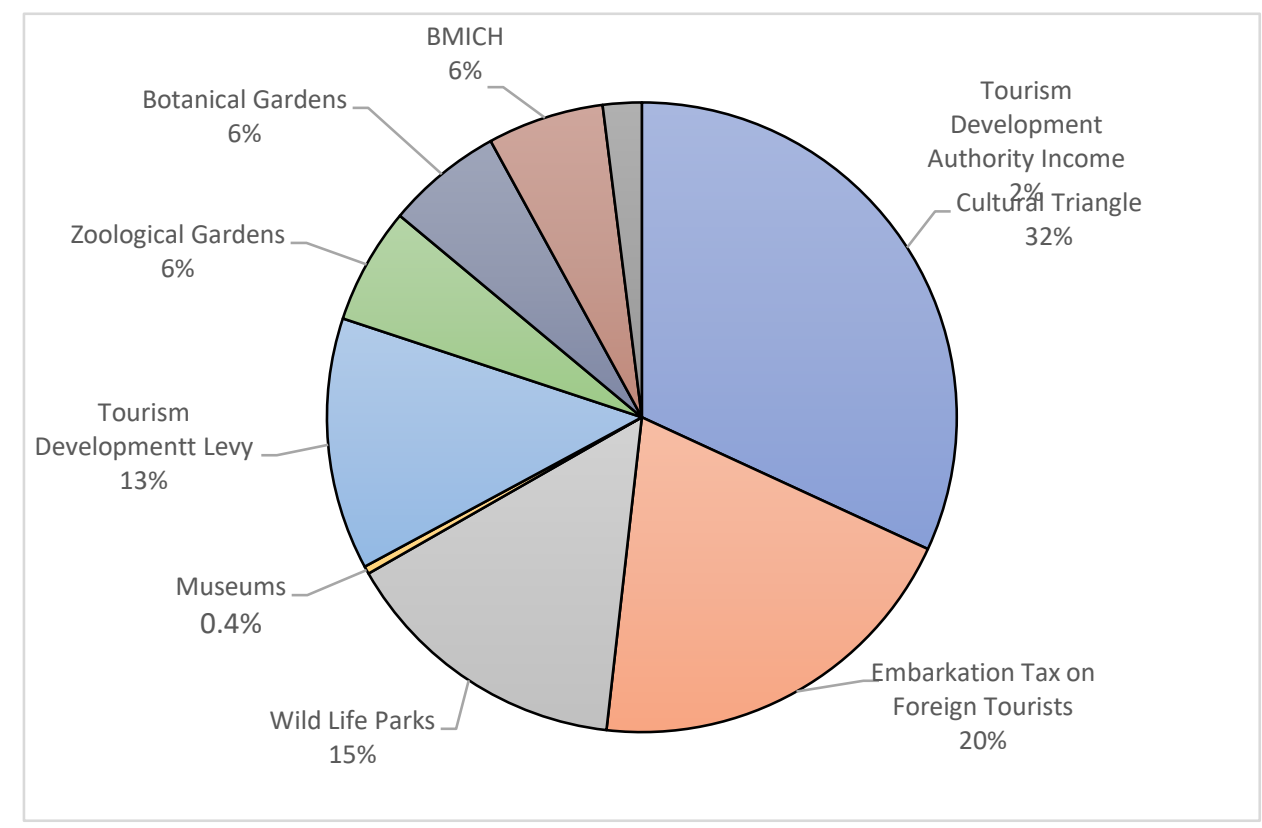

Figure 1. Distribution of Public Sector Revenue from Tourism - 2017

Source: Compiled by the author.

According to the development of job opportunities and statistical appendix show the volume of direct/indirect employment in the sector and the contribution towards the economy of the country. Public sector institutions derive revenue from tourism in a variety of ways, namely direct and indirect taxes, fees and levies, profits from business undertakings etc. However, statistics of revenue collections are readily available only from few sources, such as the Tourism Development Levy, Embarkation Tax, Income of Sri Lanka Tourism Development Authority, and entrance fee to Cultural Triangle sites, Wildlife parks, Conservation forests, Museums, Zoological Gardens and Botanical gardens and income of Bandaranayake Memorial International Conference Hall (BMICH). In the year 2017, the total revenue collected from the listed sources amounted to Rs.11,767.6 million, compared to Rs.10,630.5 million collected in the previous year excluding revenues from conservation forests. Out of the total revenue collected in 2017, the top three contributions were - Cultural Triangle Entrance fees - Rs.3,774.4 million, Embarkation Taxes - Rs.2,378.8 million and the revenues earned from Conservation Forest was Rs.25.4 million, while Tourism Development Levy, Zoological Gardens and Botanical Gardens also contributed considerable amounts recording Rs.1,541.5 million and Rs.640 million respectively.

Tourism industry is still developing after crisis environment in 2009 as large number of tourists attracted to this land. Therefore, tourist industry is boosted again with high potential in income ways and infrastructure development ways. Tourism sector directly helps to flow foreign money into the country. As a result, Sri Lanka earned over 213 million US dollars in 2001, 350 million US dollars in 2009, 575 million US dollars in 2010 and 645 million US dollars in 2011. According to study it is about 78.9\% of tourists arrive Sri Lanka to spend their holidays and most of them represent the middle-income earners. Nearly $12.7 \%$ visit Sri Lanka for business requirements and 5.4\% visit to meet their relations or pals. Under business ethics and policies, the Government has made measures to develop services in all tourist sector institutions/Hotels and registered them with Tourist Board. This is to arrange limitations and standardization methods to enhance accommodations, restaurant, transportation, and facilities for guides. Most infrastructure development projects help to enhance tourism sector and today the road network upgraded as international levels. Further to maintain principles of business they have influenced support from Ministry of Cultural Heritage. Therefore, illegal drugs, prostitutions and some harmful alcohol being banned in the environment of tourism industry even though there are challenges and threats for future tourism in Sri Lanka. It is also noticed that comfortable accommodation and restaurant facilities comprehensively renewed to enhance tourism of the country. But Sri Lanka is facing several issues in this sector with higher tourist arrivals. Comfortable accommodations and Tourist Board approved restaurant are not enough to handle the capacity of tourist sector. Past dark years conflict environment adversely affected to tourism industry, and it is vigorously affected to decline economic development of the 
country. According to history Sri Lanka survived with agriculture crops and industries but now in need to develop with much stronger and different economic strategies. Therefore, Sri Lanka needs to enhance tourism sector development with proper Government mediations. Yet Sri Lanka is a great tourism destination and it is popular among most Europeans.

Table 4. Foreign Exchange - Earnings 2016 \& 2017

\begin{tabular}{|l|c|c|c|}
\hline Year & $\begin{array}{c}\text { Foreign Exchange Earnings Rs. } \\
\text { Mil. }\end{array}$ & $\begin{array}{c}\text { \% of total Foreign } \\
\text { Exch. Earnings }\end{array}$ & $\begin{array}{c}\text { Local } \\
\text { Rank }\end{array}$ \\
\hline 2016 & 512,593 & 14.2 & 03 \\
\hline 2017 & 598,356 & 14.8 & 03 \\
\hline
\end{tabular}

Source: Compiled by the author.

Sri Lanka is very optimistic about next two years. The goal we want to chase is anything between 2.5 and 3 million tourist arrivals and an income of around US\$ 5 billion, according to Chairman of Sri Lanka Tourism Promotion Bureau (SLTPB). The re4cent data by the Sri Lanka Tourism Development Authority said that an average duration of stay per person in the island country was 11 days while an average daily expenditure was 174 US\$.

\section{Social and Environmental Impact}

Travel and tourism are one of the world's largest industries, it contributes more than $10 \%$ of global GDP. Tourism is one of the major foreign income sources in Sri Lanka. Main objectives of this are to find out what are the social, political, and economic problems created by tourism and also the policy formulation for correction of the problems. Both quantitative and qualitative methods were used to define with available secondary data. Local hotel owners and tour operators claim the major portion of income, while the Government highly concerns over the foreign exchange which helps to balance the budget deficit. The irregular working hours, minimal job security or seasonal work, low wages and inflation have negatively impact on the poor community depending on the industry. On the other hand, tourist arrival is also influenced by political unrest, war crimes, strong protests, scandals, and terrorism in the country. It is also understood that tourism contributes towards the deterioration of natural environment, indigenous values, ancestry culture, customs and simple lifestyle at certain times. It is also contributed towards archaeological ruins, illegal business, black money frauds, drug trafficking, corruption, and child abuse more often. Whatever the short coming of it, the development of tourism has been regarded as a panacea for the economic malaise of Sri Lanka. Tourism is also bringing much positive benefits if it is sustainable. The Eco-tourism frequently opens formerly untouched environments to tourists and brings foreign exchange without damaging natural resources. In addition, it provides additional income to the community to reduce poverty level in certain rural areas. As the international tourism has a significant impact on the socio-cultural structure some educated middle class personnel are involved in the tourism industry. They are in various capacities such as managers and others, view that even though they are not happy with the worst aspect of European culture - specially clothing and lifestyle, but they accept tourism as country needs to earn foreign exchange in a decent manner. Yet, promotion of tourism as a means of upgrading standard of living, values fostering, international understanding, preservation of cultural heritage of the host population is not always positive.

\section{Distribution of Employment in Tourism}

Tourism has vast direct economic benefits other than from generating employment, improving wages, and stimulating growth in many direct and indirect sectors. The tourism industry in Sri Lanka has taken many hard hits before: be it a long period of a civil war lasting 27 years; someone might conclude that during a civil conflict like what it was in the Island, tourism is non-existent where many lost their jobs. The industry, which was mainly owned by local companies, struggled but stayed resilient, not losing confidence with their sights fixed on a thriving tourism economy. The Easter Sunday terrorist attack in 2019 shook the entire world and tarnished the nation's image, considered as one of the most peaceful laidback Paradise Isles. Once again, most hotels and tourist guide personnel lost their living due to 2019 attack.

When the Government struggled to maintain the tourist arrivals with never-ending strings of incidents, the tourists came certainly not in the numbers that the country deserved, but they did continue to visit, mainly the repeat visitors despite many travel warnings knowing the best hospitality offered by employees in a very much friendly way than any other destination. They even signed indemnity agreements to waive off any liabilities and enjoy most wonderful holidays in Sri Lanka. Behind this glamorous and glitzy industry facade, there is 
an army of people depending on it for their livelihood. Safeguarding livelihoods, preventing long term economic downfall are basic duties of the Government. In any incident of this nature, there are unstoppable short-term implications, immediately impacting on tourists, reducing their stay, and causing cancellations of immediate bookings. Most of these issues have bluntly affected on employees in hotel and tourism industry in a much noticeable way. Safeguarding long term economic stability is far more crucial for Sri Lanka, or it will lead to an economic disaster that would do more harm to the poorest communities across all the rural regions, as they are the most helpless and vulnerable in the society. Sri Lanka Institute of Tourism \& Hotel Management is the only Government approved premier Institute in Sri Lanka established in 1964 to train youngsters. There are many Diplomas that students could follow for their future endeavors and for better services in Tourism Industry which will be helpful to upgrade their living standards while contributing for the national income.

Under business ethics and policies, the Government has made measures to develop services in all tourist sector institutions/Hotels and registered them with Tourist Board in order to render a better service by employees. This is also to arrange limitations and standardization methods to enhance accommodations, restaurant, transportation, and facilities through skilled staff. Most infrastructure development projects help to enhance tourism sector and today the road network upgraded as international levels with much confident drivers and assistants. Further to maintain principles of business they have influenced the support from Ministry of Cultural Heritage so that tour guides and assistants will have a much advanced knowledge of all tourist attraction sites mainly archaeological and sanctuaries, whom we noticed a vast number of employees involved in. Under this programme employees are trained to avoid encouraging illegal drugs, prostitutions and some harmful alcohol being banned in the environment of tourism industry and to understand and evaluate the measures specially to maintain Sri Lankan prestige in the world. Number of establishment employment in tourism industry from 2015 - 2018 is given below according to Tourism Development Authority. This has paved foundation for opportunities and its categories. (revised)

Table 5. Categories of Establishment 2015 - 2018

\begin{tabular}{|l|l|c|c|c|c|}
\hline & \multicolumn{1}{|c|}{ Category } & 2015 & 2016 & 2017 & 2018 \\
\hline 01. & Hotels/Restaurants & 2,196 & 2,378 & 2,567 & 2,810 \\
\hline 02. & Travel Agent/Tour Operators & 758 & 855 & 864 & 904 \\
\hline 03. & Airlines & 28 & 28 & 28 & 32 \\
\hline 04. & Recreational facilities & 71 & 76 & 80 & 80 \\
\hline 05. & Tourist shops & 66 & 70 & 73 & 78 \\
\hline 06. & State tourist organizations & 4 & 4 & 4 \\
\hline
\end{tabular}

Source: Compiled by the author.

\section{Economic Growth Through Tourism}

The economic contribution of Travel and Tourism was at $12.5 \%$ in 2018, up from $11.7 \%$ previous year. The share of Travel and Tourism spending or employment in the equivalent economy-wide concept in the published national income accounts or labour market statistics. Tourism income is one of the important segments that contribute to the Sri Lankan economy. Recent trends of Sri Lanka Gross Domestic Production (GDP) shows a significant role which played by the service sector indicating $60 \%$ contribution. Island economies such as Bahamas and Maldives secures half of their Government revenue from tourism where Sri Lanka it remains at the fifth place in terms of foreign revenue earning items. Thus with the eye to clarify the relationships between tourism income and economic growth of Sri Lanka this explores the significant variables contributed to tourism income and their relationships with the overall GDP. It is also researched and identified the relationship between economic growth and tourism income in terms of microeconomic variables in the country. In order to develop the economic growth through tourist arrivals, the Government has made measures to upgrade services through International airports and harbours in 2018 Viz:

$>$ Katunayake International Airport - 96.28\%

$>$ Mattala International Airport $-0.04 \%$

$>$ Colombo Harbour $-2.94 \%$

$>$ Galle Harbour $-0.62 \%$

$>$ Other $-0.12 \%$ 
According to the Department of Immigration and Emigration, tourism industry is promoting to lengthen the stay of foreigners who are visiting the island for various purposes by advancing infrastructure facilities and fringe benefits, mainly those who are visiting for leisure vacations, business purposes and others. The declared objectives of this promotion is to attract tourists and to increase their revisits to the country in order to develop the economy where European average duration of stay 13.9 and Asian region average is the lowest of 7.2. According to statics the average duration of stay of tourists in Sri Lanka has declined from 10.90 to 10.80 nights in 2018.

Table 6. Occupancy Rates by Resort Region 2016 \& 2017

\begin{tabular}{|l|c|c|}
\hline \multicolumn{1}{|c|}{ Resort Regions } & Occupancy 2016 & Occupancy 2017 \\
\hline Colombo City & $76.75 \%$ & $75.31 \%$ \\
\hline Greater Colombo & $75.18 \%$ & $73.14 \%$ \\
\hline South Coast & $74.24 \%$ & $72.38 \%$ \\
\hline East Coast & $74.92 \%$ & $72.95 \%$ \\
\hline Hill Country & $75.24 \%$ & $73.55 \%$ \\
\hline Ancient Cities & $75.46 \%$ & $73.85 \%$ \\
\hline Northern Region & $69.58 \%$ & $70.98 \%$ \\
\hline
\end{tabular}

Source: Compiled by the author.

Table 7. Hotel occupancy in 2019 and 2020

\begin{tabular}{|l|c|c|}
\hline \multicolumn{1}{|c|}{ Month } & 2019 & 2020 \\
\hline January & 244,349 & 228,434 \\
\hline February & 252,033 & 207,507 \\
\hline March & 244,328 & 71,370 \\
\hline April & 166,975 & - \\
\hline May & 37,802 & - \\
\hline June & 63,072 & - \\
\hline July & 115,701 & - \\
\hline August & 143,587 & - \\
\hline September & 108,575 & - \\
\hline October & 118,743 & - \\
\hline November & 176,984 & - \\
\hline December & 241,663 & - \\
\hline
\end{tabular}

Source: Compiled by the author.

Under the details of the Tourism Development Act No.14 of 1968 it is eligible to pay a levy of $1 \%$ on turnover and levy would not be charged on the turnover of any General Sales Agent licensed under the Tourist Development Act with effect from $1^{\text {st }}$ January 2004. The Director General of the Ceylon Tourist Board will retain the entirety of the Levy collected under subsections. He shall also furnish such returns in such manner as may be prescribed in that behalf to the Deputy Secretary to the treasury, within thirty days. Turnover is determined by the total receipts from services provided in relation to the tourist industry, excluding payments made by the Travel Agent in respect of services provided to him by other local service providers and the value-added tax charged on such sales in terms of the value Added Tax Act.No.14 of 2002.

Progress of Investment Projects up to December 2019

\begin{tabular}{|l|c|c|c|}
\hline \multicolumn{1}{|c|}{ Status of the Project } & No. of Projects & No. of Rooms & Investment US\$ Mil. \\
\hline $\begin{array}{l}\text { Construction in } \\
\text { Progress }\end{array}$ & 110 & 6,966 & 975.05 \\
\hline Not yet started & 76 & 3,523 & $1,020.91$ \\
\hline In operation & 221 & 10,462 & $1,785.59$ \\
\hline Final approvals & 407 & 20,951 & $3,781.55$ \\
\hline
\end{tabular}

Source: Compiled by the author.

Sri Lanka's fragile economy depends on tourism could get worse due to the following decades of conflict, Sri Lanka was making steady if uneven headway towards economic development. The recent attack of Easter Sunday 2019 could set the economy back years and have deep social ramifications. In the year 2009 nearly 447,890 tourists visited Sri Lanka after 27 years of civil conflicts but by 2018 about 2.3 million tourist visited and brought 3 billion USD to the country. According to the World Bank, Sri Lanka is significantly reliant on tourism receipts to counteract weakened remittances and high interest payments on foreign loans. The tourism industry is labour intensive and as a result, has a high impact on lowering the unemployment rate. Tourists visiting 
Sri Lanka bring with them much needed hard currency which the country desperately needs to pay off its debts, much of it owed to China.

The total tourism based direct employment in 2017 is as $81.52 \%$, who were employed in Hotels and Restaurants. Travel agents and tour operators accounted for $6.36 \%$, Airlines $4.8 \%$, Guides $3.18 \%$, State sector $1.71 \%$, Tourists shops $1.30 \%$, Recreation centres $0.64 \%$ and National Tourism Organization $0.47 \%$ shows the contribution and the development of the industry. But considering Covid 19 pandemic a ban on all in-bound visitors to Sri Lanka was introduced in mid-March 2020, therefore a 62\% drop in travel interest is observed and a drop of tourist traffic was $76 \%$. In these troubling times, tourist industry considers complete or temporary shout downs of staff layoffs and other economic cost cutting measures which could lead for a downfall of economy. When visiting Sri Lanka for any purpose tourists should obtain Visa prior to arrival or on arrival to Sri Lanka which can be added to income as well. Visa cost will vary according to the purpose of visiting for leisure to business through standard processing to super rush processing depending on the duration of their stay. For each processing of 'Visa' can cost high price and others will be charged from 70 USD to 120 USD which will add to tourism income. Further to attract tourism there are various other avenues controlled by the Government and private entrepreneurs. Handicraft, clothing, guest shops, souvenirs and food parlours are a few of them which displays Sri Lankan culture and pride to the world while earning for the nation. Laksala, Lak Pahana, Barefoot are the most prominent tourist shops in Sri Lanka as well as other tourists shops around the island. These would supply a chain of goods to impress the cultural values to tourists and most tourists visits these shops in order to purchase clothes, wall hangings, masks, Batick designed fabrics, all types of jewellery, brassware, traditional souvenirs, wooden ornaments and items, woven bags-mats-pouches etc., and cane and leather products. These crafts shops continue to maintain their traditional flare and quality with a high price which added colours to the economy while Government is granting loan schemes and concessions in various fields for tourism. According to the economic contribution through tourism, distribution of monthly salaries are added with the collection of commissions after sales as mentioned below -

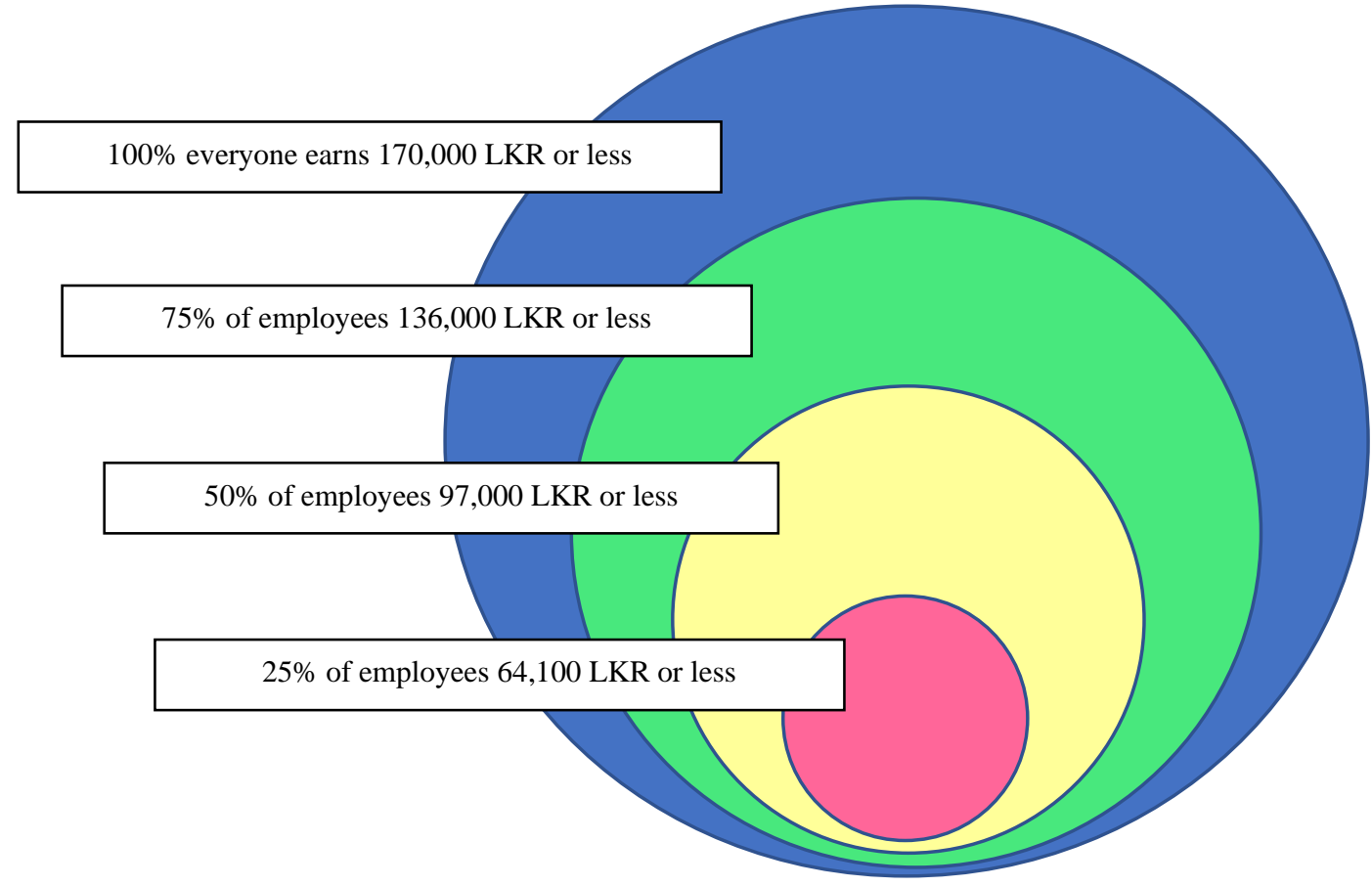

Figure 2. Distribution of Monthly Salaries

Source: Compiled by the author.

Further to develop tourism Ministry of Foreign Relations planned projects with workshops for employees with Indian Outbond Tour Operators Association to support the economy of Sri Lanka through tourism. Sri Lanka offers a wide array of shopping items to the international standards but maintaining traditions to a high price viz: gems, batik, tea, antiquities, and other handicrafts. Tourism also offers an advanced Ayurvedic herbal treatment which is very famous among most tourists according to their wishes and needs, that adds much of income to the economy every year. Further to promote tourism all Duty-Free shops are offering discounts over $10 \%$ for Master Cards for most commodities. As well as State Banks and Private Banks are also located in 
both arrivals and departure lounges at International Air Port in Colombo in order to accept on line payments which is much efficient and convenient for all tourists. The Finance Ministry has issued a fresh gazette to revise the Value Added Tax (VAT) 7\% charged on services rendered by a hotel, guest house, restaurant or other similar business providers to tourism. But the Easter Sunday attack of 2019 targeting several star class hotels impacted country's tourism industry bringing it to a near standstill overnight. Therefore, Finance Ministry has granted concessions for loan recoveries to strengthen the industry and its being formidable.

\section{Conclusion}

As tourism is a vector of development, Government is trying to coordinate and plan with national development objectives. Sri Lanka a post war country, tourism has been perceived as a tool for post war reconstruction and reconciliation.

So, "Sri Lanka" (Ithin Sri Lanka - in state language Sinhala) is the latest tourism tagline replacing "Wonder of Asia". The new moto was introduced by Sri Lanka Promotion Bureau who says that new tagline will be very natural, simple, and highly adaptable.

Recently due to COVID 19 Pandemic the Ministry of Tourism and Aviation has issued a new operational guideline under the caption of Preparedness and Response for Covid 19_Outbreak for Tourism Industry in May 2020. Therefore, tourist arrivals and issuing Visas have been suspended from all countries until further notice. Sri Lanka is making plans to draw tourists after Corona virus crisis, with a raft of new operating rules for hotels, transport and to protect workers and their families in the industry.

\section{Acknowledgement}

Sri Lanka Tourism Development Authority

No. 80 Galle Road, Kollupitiya,

Colombo 3, Sri Lanka.

www.sltda.lk

\section{References}

1. Sri Lanka Tourism Development Authority. (2019). Annual Statistical Report. [Link]

2. Abeysinghe, B. (2014). The time has come for Sri Lanka to look beyond apparel exports. Daily FT. [Link]

3. Caleb, G., Mazanai, M. and D. Netsai. (2014). Relationship between international trade and economic growth: A Cointegration analysis for Zimbabwe. Mediterranean Journal of Social Sciences, 5(20), 621 627. [Google Scholar]

4. De Silva, N., Chidmi, B. and Johnson, J. (2013). Trade liberalization, openness, and economic growth in Sri Lanka: A Co-Integration analysis. GSTF International Journal of Engineering Technology, 2(2), 1-8. [Google Scholar]

5. Deyshappriya, N. R. (2020). Dynamics of Travel Behaviour and Mode of Travelling during COVID-19 Outbreak. Evidence from South Asian Countries. Evidence from South Asian Countries. Social Science Research Network. [Google Scholar]

6. Tharshan, S., Liyanage, W. L. M. A., Nilakna, P. G. K., Selvanathan, E. A., Jayasinghe, M., \& Selvanathan, S. (2019). The Impact of Sectoral Government Expenditure on Economic Growth: Evidence from Sri Lanka. (The Economics and Business Statistics Discussion Paper Series). Griffith University, 1-11. [Google Scholar]

7. Mohamed Aslam, A.L. (2016). Impact of Money Supply on Sri Lankan Economy: An Econometric Analysis. International Letters of Social and Humanistic Sciences, 67, 11-17. [Link]

8. Export Development Board (EDB). (2012). Industry Capability Report of Export Development Board. [Link]

9. Lakshman, W. D. \& Tisdell, C.A, (1997). Sri Lanka's Development from Independent-Socio- Economic Perspectives and Analyses. Huntington, New York: NOVA Science Publishers. [Link]

10. Tourism in Sri Lanka/Daily Mirror. [Link] 
11. Sigala, M. (2004). Using data envelopment analysis for measuring and benchmarking productivity in the hotel sector. Journal of Travel \& Tourism Marketing, 16(2-3), 39-60. [CrossRef]

12. Tan, Y. (2017). Hotel-specific, industry-specific and macroeconomic determinants of profitability in London hotel industry: Structure-conduct-performance or efficient-structure hypothesis? [CrossRef]

13. Kim, H. J., Chen, M.-H., Jang, S. (2006). Tourism expansion and economic development: The case of Taiwan. Tourism Management, 27(5), 925-933. [CrossRef]

14. Jayathilake, P. M. B. (2013). Tourism and economic growth in Sri Lanka: Evidence from cointegration and causality analysis. International Journal of Business, Economics and Law, 2(2), 22-27. [Link]

15. Chen, M.-H. (2010). The economy, tourism growth and corporate performance in the Taiwanese hotel industry. Tourism Management, 31(5), 665-675. [CrossRef] 